\title{
The meaning of social media for women domestic workers during the Covid-19 pandemic
}

Nuria Astagini

Student of Postgraduate Program of Communication, Universitas Indonesia, Indonesia

Email: nuria.astagini@gmail.com

Billy K. Sarwono

Lecturer at Departement of Communication, Faculty of Social and Political Sciences, Universitas Indonesia, Indonesia

Email: billysarwono@gmail.com

\begin{abstract}
Social media plays an important role during the Covid-19 pandemic, where physical activity and community mobility are limited. Especially for women who work as domestic workers who live with their employers. Social media is the only means for them to connect with the outside world. Previous studies have shown that a person's identity can be shown through the front stage and the back stage. Theoretically, this study analyzing how women domestic workers identify themselves through the online realm using social media. This study uses a constructivist paradigm and a qualitative approach. The research participants were three women domestic worker who were obtained purposively using the snowball sampling technique. Data was collected through in-depth interviews and observation to participants. The results of the study show that social media allows participants to construct a reality in the online realm that is different from their situation in real life. Therefore, social media has a very
\end{abstract}


important meaning for participants, because with social media, participants feel their position is equal to other users. They also have access to create a front stage and a back stage, where they can create their ideal self-identity. The aspect of self that are presented by the participants on the front stage is individuals who are successful and happy with their lives. For participants, this is an aspect of their ideal self, even though it does not represent their actual state.

Keywords: Women, Domestic Workers, Social Media, Covid-19, Meaning

\section{INTRODUCTION}

The Covid-19 pandemic has caused many changes in social life, and the rapid viral spread made the government implement various new rules such as prohibitions to limit mobility, avoid crowds, and maintain social distancing (Azeez E P et al., 2021). In Indonesia, the Large-Scale Social Restrictions (PSBB) policy was implemented and later replaced by the Enforcement of Restrictions on Community Activities (PPKM). This policy limits the various activities and mobility of people in daily life (Krisdiyanto, 2021; Sigiro et al., 2020) and impacts society, including women domestic workers.

Women domestic workers can be classified into two groups. The first is live-in women domestic workers, who live with their employers, while the second group comprises live-out workers, namely those who live outside the employer's house (Burnham \& Theodore, 2012). The live-out workers have flexible working hours, adapting to their employer's needs (International Labour Organization, 2013). Meanwhile, live-in domestic workers who have worked for a long time have a personal closeness with their employers (Galvaan et al., 2015). However, as workers, they want to be free and independent of supervision and interact with others (Pandey et al., 2021).

Before the Covid-19 pandemic, women domestic workers had space to interact directly. However, the enactment of the PPKM policy limits face-to-face interactions and prevents workers from returning to their hometowns to meet their families (Anggraeni \& Diyana, 2020). Therefore, social media has become the main tool for communicating and interacting with other people during this pandemic. It can also fulfill the needs of women domestic workers who live with their employer to communicate with their colleagues and families, express their identities, and connect with the environment outside their workplace (Platt et al., 2016). 
Several previous studies have shown that women domestic workers use social media as a means of communication, a source of information, and entertainment (Platt et al., 2016; Azeez E P et al., 2021). It is also a medium to express, organize, and voice their narratives (Retnaningdyah, 2013; Ujianto, 2019). For women domestic workers who often get a lowly position in society, they need space to equalize their position. Social media can be a safe space for women domestic workers to build their ideal self-image which equal to other users, because it is able to facilitate their self-presentation detached from their profession as domestic worker.

This study will analyze the meaning of social media for women who work as domestic workers. This study uses a dramaturgical approach that provides an understanding of how individuals identify themselves on social media that serves as an individual's front stage and back stage. The use of this approach refers to the research by Bullingham \& Vasconcelos (2013); Hogan (2010); and Djafarova \& Trofimenko (2019) which provided explanation that the dramaturgy approach was the most appropriate approach for studying the individual and social media.

\section{LITERATURE REVIEW}

\section{Dramaturgy in Social Media}

Dramaturgy approach explains that when an individual is in front of others, they will present their ideal self, and not showing their true condition. Therefore, individuals are then likened to performers because they present themselves according to the expectations of others who observed them. The individuals then actively modify their behavior and impressions they want to convey to others. This process is known as impression management (Hogan, 2010which take place in synchronous "situations," and artifacts, which take place in asynchronous "exhibitions." Goffman's dramaturgical approach (including the notions of front and back stage, Djafarova \& Trofimenko, 2019).

In performing impression management, individuals present themselves through two different settings, namely the front stage and the back stage. The front stage occurred because of the individual need to present themselves with a certain impression to a specific group of people or audience. While the back stage is a hidden space where the individuals present themselves differently from what they showed on the front stage (Hogan, 2010). Although there are 
two different stages, it does not mean that individuals change their identity. Rather it is as if the individual is wearing a mask where they act according to the social influences on both stages (Kerrigan \& Hart, 2016).

Self-presentation is very important in the context of social media, because each user shares a lot of information about themselves with other users through written and visual communication. Through self-presentation, social media users gain acceptance and build relationships with other users (Djafarova \& Trofimenko, 2019). Social media allows users to present a different identity, because they have various features which facilitate users to hide certain aspects of themselves that visible in the offline realm and modify it in the online realm (Kerrigan \& Hart, 2016; Bullingham \& Vasconcelos, 2013). Social media also has certain settings where users can approve other users to their network and selected certain information conveyed to the audience. This shows that social media is a perfect media in facilitating individuals in performing impression management (Djafarova \& Trofimenko, 2019; Bullingham \& Vasconcelos, 2013).

\section{Interaction in Social Media}

During the Covid-19 pandemic, individuals interacted a lot through mediated communication using social media (Davis, 2014; Redmond, 2015). The number of social media users, in general, has also increased during this Covid-19 pandemic. Social media is known to be an important tool to achieve the desired quality of life (Putri \& Zakiah, 2021). Generally, the meanings of social media formed by individuals emerge through their interactions on various platforms (Markham \& Lindgren, 2014). The content displayed through text, video, photos, and sounds can influence the meaning and actions of individuals online and offline. There is connectivity, as each user can participate in the content creation (Davis, 2014; Wang et al., 2019).

Social media is a space where self-concept, identity, and interaction are transformed digitally (Housley, 2021). Another important aspect is that social interaction on online media is a safe space for individuals to create themselves and interact (Wängqvist \& Frisén, 2016). Individual self-concept in social media is called cyber-self and arises through interactions between users, where individuals can position themselves as subjects (I) or objects (Me) (Davis, 2014; Redmond, 2015). Furthermore, individuals learn to negotiate between public and private self, as well as present themselves on the front and back stages respectively. This self-presentation is to attract and retain their audience or 
connected people on social media (Housley, 2021).

There are several characteristics of this interaction, such as being majorly performed visually through symbols (Wang et al., 2019), requiring constant individual attention, and being hindered by distractions between users (Housley, 2021). Hence, social media allows users to accept friendship invitations from people in their closest environment, alongside those they do not know. In this context, individual friendship networks can be divided into two categories. First, people considered the closest parties to individuals in the virtual realm, called the virtual significant other, and second, general norms internalized by individuals of the public from using social media, also known as the virtual generalized other. Then, communication mediated with the network of friends becomes an important part of forming an individual's self-concept (Davis, 2014; Redmond, 2015).

In mediated communication, interaction is implemented through symbols, and individuals act based on the associated meaning. The majority of interactions on social media use visual communication aspects (Vardanega, 2015). Some user behaviors can be categorized as social interactions and reflect engagement, namely giving a "Like" or "Love" sign, uploading content, and leaving comments. High engagement is shown through interaction with the uploaded content and comments, while a low level is indicated by the "Like" or "Love" sign (Wang et al., 2019). This behavior can be interpreted as appreciation, establishing interpersonal relationships, and as a symbol of activeness in interacting (Wang et al., 2019).

\section{Women Domestic Workers and Social Media}

Domestic work is one of the jobs that womens do the longest, also known as "lifelong work." This means that these individuals start working for the employer's family from a very young age and stay with them for the rest of their lives (International Labour Organization, 2013). Previous studies have shown that employers choose live-in domestic workers because they need individuals that are ready to work at any time and can be trusted to manage their various household tasks (Galvaan et al., 2015).

Several conditions that require women domestic workers to live with their employers cause the boundary between work and personal time to disappear, as they can never leave their job environment even after completing their functions. Hence, social media becomes a means of entertainment and provides personal space for women domestic workers (Platt et al., 2016). Since 
this Covid-19 pandemic, the role of social media has become more significant because it helps individuals overcome loneliness caused by the inability to interact directly (Cauberghe et al., 2021).

Studies conducted by Retnaningdyah (2013), Ujianto (2019), Sari \& Siahainenia (2015) showed that women domestic workers have digital literacy skills to use social media to communicate. Also, they use it to convey the narrative that they have another side of life besides being domestic workers. They are not limited by negative societal constructions from showing and empowering themselves and can express their identity as autonomous individuals. Therefore, the availability and access to the internet network at the employer's home are currently important aspects for live-in domestic workers (Platt et al., 2016).

Currently, some women domestic workers work as content creators on social media, such as Farida Nurhan. This former domestic worker achieved vertical mobility and changed professions to become a food vlogger and property broker with 3.54 million subscribers on Youtube presently. There are also Mboke Memey and IsaYang 123, with more than 600 thousand subscribers. The success and fame gained by these women domestic workers show that they can escape the neglect and negative stereotypes in society. Therefore, these workers select the audience or brand friendship networks to create an audience that supports and rewards them (Astagini, 2016). Support and appreciation are given through the "Like" or "Love" sign, as well as positive comments. These symbols are the benchmarks for users to present themselves and select their various content (Wang et al., 2019).

The theoretical assumption in this research is that social media has an important meaning for women domestic workers, because through social media they can construct and identify their ideal self apart from their profession. Social media has various features that facilitate them to present themselves according to the expectations given by their friends and families. The new selfidentity that is owned by women domestic workers makes them feel equal to other social media users. Previously in offline realm, it is difficult for women domestic workers to present themselves ideally. Because when others know their profession, these women domestic workers tend to be positioned in a lower position than others. Thus, social media where social media is very meaningful for women domestic workers because it is a safe space for them to communicate and interact with other users equally. 


\section{METHODS}

The focus was the meaning of social media for women live-in domestic workers. Therefore, this study applied a constructivist paradigm to explore the meaning of social media for these individuals. By using a qualitative approach to explore and understand the meanings held by individuals or groups (Creswell \& Creswell, 2018), researchers can enter into the subject's environment and see reality from their perspective. Data collection was performed for approximately 6-12 months to the research participants.

The first step is to determine the criteria for research participants, as follows: women, working as domestic workers with a minimum period of one year. The criteria for working period refer to the duration of the probationary period for domestic workers (de Villiers \& Taylor, 2019; Tomei, 2011). The domestic workers who have passed this probationary period are considered permanent workers. The next criterion is over 18 years of age. The determination of this age limit is according to the law which stated that all people under the age of 18 are categorized as children, therefore they cannot give consent to become participants in the research. (International Labour Organization, 2006; Hidayati, 2011)

Furthermore, participants must have active social media accounts, and have access to use these social media while they work as domestic workers. Due to the limited access of researchers to research participants, the researchers used a snowball sampling technique, in which access to research participants was obtained through their employers who were colleagues of the researchers. At first there are 10 women domestic workers who were willing and got permission from their employers to become research participants. However, because this research was conducted during the Covid-19 pandemic, only seven women who are given the permission to be interviewed face-to-face.

In the middle of the data collection process, there were two participants who stated that they had changed their mind and resigned as research participants. Meanwhile, there were several other participants who returned to their hometowns because they were terminated due to the Covid-19 pandemic. This condition requires researchers to find new participants who meet the criteria, give consent and get permission from their employers to be involved in this research. Three women domestic workers were selected as research participants, taking into account that the number of participants had reached saturation (Creswell \& Creswell, 2018). The following table is descriptions of research participants 
Table 1: Background of Research Participants

\begin{tabular}{|c|c|c|c|c|c|c|c|}
\hline Participants & Age & $\begin{array}{l}\text { Educa- } \\
\text { tion }\end{array}$ & $\begin{array}{c}\text { Marital } \\
\text { Status }\end{array}$ & Origin & $\begin{array}{l}\text { Work } \\
\text { Period }\end{array}$ & $\begin{array}{c}\text { Number } \\
\text { of Active } \\
\text { Social } \\
\text { Media } \\
\text { Account }\end{array}$ & $\begin{array}{c}\text { Frequency } \\
\text { Accessing } \\
\text { Social } \\
\text { Media }\end{array}$ \\
\hline 1 & 22 & SMP & Single & $\begin{array}{l}\text { West } \\
\text { Java }\end{array}$ & 2 years & 3 & $\begin{array}{l}3-5 \text { times/ } \\
\text { day }\end{array}$ \\
\hline 2 & 21 & SMP & Single & $\begin{array}{l}\text { Central } \\
\text { Java }\end{array}$ & 2 years & 3 & $\begin{array}{l}3 \text { times/ } \\
\text { day }\end{array}$ \\
\hline 3 & 32 & SMP & Married & $\begin{array}{l}\text { West } \\
\text { Java }\end{array}$ & 5 years & 3 & $\begin{array}{l}2-3 \text { times/ } \\
\text { day }\end{array}$ \\
\hline
\end{tabular}

Source: Research data

The researcher then conducted face-to-face in-depth interviews with each participant. These interviews were conducted twice, with the duration approximately one hour each, due the available time of the was participant's limited, and considering the interviews were conducted during the Covid-19 pandemic. The interview was conducted at the employer's house, and to confirm some of the participants' answers, the researcher contacted the participants through WhatsApp messaging. Outlined questions for participants were correspond with the use of social media during the pandemic, and their self-presentation in social media. In addition researchers also conducted observations on the daily lives of participants and the social media accounts owned by participants. Literature review on previous studies which analyzed women domestic workers and social media also conducted.

Data analysis was conducted with open coding, axial coding and selective coding. Open coding and axial coding were used to facilitate data classification into dominant categories or themes. Axial coding results showed that there were four dominant themes as follows: the use of social media, interaction on social media, self-presentation on social media and the meaning of social media, especially during the Covid-19 pandemic. Meanwhile, the results of selective coding showed that through social media, the participants were able to identify themselves according to the expectations of other users, but they were also able to express themselves detached from their ideal self. 
Goodness criteria in this research achieved from two aspects: credibility and confirmability. Credibility obtained through various stages in the research ranging from data collection both literature studies, interviews and observations, data analysis and data interpretation. Confirmability in this research obtained through triangulation. This research conducted triangulation of data and triangulation of methods. Triangulation of data was done by collecting data on a topic from various sources; to determine whether different sources provide different information. Meanwhile, triangulation of methods was done by using different technique in data collection process as follows in depth interview, observation and literature study.

The duration of this study took quite a long time, because the researcher realized that there were differences in authority and social position between researchers and participants. This difference can lead to unequal positions in the data collection process and affect the quality of the data obtained. Therefore, the researcher must build a rapport with the participants before conducting data collection, in order to obtain preliminary data regarding the participants and to make the participants feel comfortable with the researcher.

\section{RESULTS AND DISCUSSION}

\section{The Use of Social Media by the Participants}

The participants explained that they became more frequent in accessing their respective social media accounts during the pandemic, as explained by participant 3 as follows : "Before the pandemic I used to open social media a lot, now during this pandemic it's even more frequent". Similar statements were also explained by two other participants. This is due to the reduced activity and work outside the employer's home. Currently, they spend more time in the employer's house and using chat applications and social media to communicate with their families and friends. Meanwhile, they do not need to allocate a certain amount of funds to buy an internet quota; because during the pandemic their employer subscribed to a Wi-Fi based internet service. They are allowed to access the internet through a Wi-Fi connection provided by the employer.

The result of the study showed that the participants in this study have three accounts in different social media platforms, namely Facebook, Instagram, and TikTok, with different purposes. Facebook and Instagram are used to upload various content about themselves and to interact with family and friends, while 
TikTok is mostly used for entertainment enjoyed on the sidelines of their busy lives. As explained by participant 2 as follows: "I have a Tik Tok account. But I created the account because it became popular. I'm not really a Tik Tok user, really. I just like to watch the videos that appeared in my FYP".

Furthermore, the participants explained that they already had at least one social media account before migrating to the city and acquiring jobs as domestic workers. The earliest account was Facebook, where they have a network with family and friends in their hometown. Generally, the content uploaded and shared through this account is a variety of general information that describes their current state.

Although the network on Instagram is less than Facebook, it is currently the most used social media platform. The three participants explained that most of their followers on Instagram were people known from work, cyberspace, and some friends from their hometowns. They stated that the accounts followed are very diverse, including celebrity, religious or da'wah, motivational, and various gossip accounts about Indonesian celebrities. The explanation given by the participants showed that Instagram is currently the main source of information.

In addition, the results showed that Instagram is more personal than Facebook, as various contents uploaded on the application express their feelings. The participants feel freer to upload and share content on Instagram because their accounts are not followed by many people. Conversely, they are more cautious with Facebook and often select the content uploaded because the platform's network comprises their family, relatives, and friends from their hometowns. Therefore, they are very careful with the content they uploaded, because it can potentially become a source of conversation by their family and neighbors back home. The participants also mentioned that only using their real name in their Facebook account, as explained by participant 3 as follows: "My Facebook account is on public setting, but my other social media account I make it private. It's secret you know. I don't use my real name on my Instagram account, but on Facebook, I used my real name".

The three participants explained that they enjoyed the contents found on TikTok. Which is why they often accessing their Tik Tok account, even though they never or rarely upload content on this social media platform. They explained that TikTok provided the entertainment they needed during the pandemic, ranging from various viral videos, culinary, to motivation videos. By accessing this social media platform, they felt connected to the outside world. 
Participants 2 and 3 explained that so far, they had never made and uploaded content on TikTok, because they did not have enough time and convenient space in order to create Tik Tok videos. However, this situation was not experienced by participant 1 . She explained that she often made various TikTok videos during her work breaks, though only a few were uploaded. She stated these videos were made by following the latest viral trends, just like other users.

The discretion owned by participant 1 to make various TikTok videos is related to her close relationship with her employer, as indicated by the observation results. Since participant 1 has worked with the employer since graduating from middle school, she positioned her employer as a protective older sister. Hence, the employer allowed her to access, upload various content, and make friends on social media, especially Facebook and Instagram. Even her employer sometimes invites participant 1 to make TikTok videos together.

Different situations were observed from participants 2 and 3's relationship with their respective employers, which were considered more conservative. They were given rules regarding the use of social media, resulting in settings and limitations of the content that can be uploaded. During the interview, they objected to providing information about their accounts, as they are private. Participants 2 and 3 were also not friends with the employers on social media because they considered social media as a safe space that releases them from their employer's control. This situation explained by participant 2 as follows: "My social media account is not private, I just don't make friends, or follow their family here (employer). I'm afraid I'll make a mistake".

Based on their explanation, the use of social media cannot be separated from the employer's supervision, as some rules should be obeyed regarding uploaded content, making it limited. Furthermore, they often get reprimands regarding the time they spend accessing social media, as explained by participant 3 as follows: "I am often insulted, as my employer would say, "you often update social media content,' even though I am finished with work and just got hold of my cellphone."

\section{The Participant' Interactions on Social Media}

In this study, the majority of interactions on social media were at a low engagement level. They often put the "Like" or "Love" sign on various useruploaded content in their network of friends. Also, these signs are a symbol of 
active interaction and the willingness to establish interpersonal relationships with family and friends.

Also, the participants explained that they hoped providing the sign would help the content uploaded obtain a lot of "Likes" or "Loves" from other users, showing that these signs symbolize their existence. The number of "Likes" or "Loves" obtained from other users makes them happy, as it means their existence is known and acknowledged. It also making them feel valued by the acknowledgment obtained from social media interactions, as explained by participant 1 as follows: "I'm really happy if someone likes my post or leaves a good comment".

For high social media engagement level, the reflecting actions were rarely performed by the participant. They explained that uploading content was only at certain moments because sufficient preparation is required. For instance, they take several pictures before finally uploading one picture that they considered the best. Likewise, before writing statuses on their social media, they looked for the correct information first to ensure the uploaded content is understood by others, showing that the participants are not rash in uploading content or writing statuses. This is done to maintain their positive image in front of their network of friends on social media. All the uploaded content must be perfect to receive positive feedback from other users.

This is also related to interactions through comments made by other users about the content uploaded by the participants. They explained that positive comments, which provide solace during their busy lives, were expected from other users, hence they carefully selected each content. However, negative comments were often found on participants uploaded contents, to which they responded by ignoring the negative comments. They are not deleting, or blocking the user in question. This is explained by participant 3: "of course I get annoyed if I get bad comments, But, that's all. Bad comments reminding me to upload a better content next time."

The participants chose not to remove or block other users because they do not want their circle of friends in social media to decrease. They defined their social media friends or followers as the people who liked them. They explained that making many new friends on social media made them happy. This is related to participants' working conditions. With their workload, it will be very difficult for them to establish relationships with other people. So they substituted it with relationship within their network of friends on social media. In fact, they only know half of their friends or followers offline, while 
the rest interact with them only on social media. Therefore, participants rarely comment on content uploaded by unknown users and only respond to their family or friends.

This shows that although the participants feel happy to have a wide network of friends, they are always careful with interacting on social media. They feel presentation on social media is very important, causing them to select every content before uploading. Through virtual interactions, they achieve pleasure and happiness, alongside feel valued and acknowledged due to the various "Like" or "Love" signs and positive comments left by other users. Generally, these feelings are not experienced in their daily lives as domestic workers.

\section{The Self-Concept of the Participants on Social Media}

The results of the study showed that the three participants did not put their social media accounts in private settings. They explained that there were no secrets and wished to expand their network of friends on social media. Therefore, each participants listed their real identity on their Facebook and or Instagram accounts, even though but used names that did not refer directly to their identities on TikTok. The data obtained also showed that the ideal self-concept presented through their social media accounts includes happiness, success, and equality, as explained below:

a. People who enjoy their life.

The three participants on social media wished to present a selfconcept as people who enjoy lives. Therefore, their uploaded contents express happiness and pleasure, such as a photo smiling or laughing, using a background of bright colors. They also edit photos by adding certain filters to enhance the brilliance, and their statuses show gratitude for the present life. Occasionally, various emoticons that show happiness are added, such as the smiling, laughing, and clapping types, and some of their re-uploaded content shows gratitude, joy, and optimism. To show this content, the participants use various editing features available on their cell phones and social media. This is explained by participant 1 as follows: "Yes, it must be changed, you can use a filter. You must show that you look beautiful. I don't want to look normal"

This self-concept is deliberately displayed to hide their difficult working conditions, as they had to leave family and friends at home and live in a stranger's house in order to get jobs as domestic workers. The three participants, now around $20-30$ years old, have been in this profession 
for approximately two to five years. This shows that they were burdened with the responsibility of earning a living, adapting or adjusting to their employers, and completing tasks at a very young age, even without previous experience in performing household chores.

However, the participants felt proud because they were trusted with supporting their families to improve economic conditions at a very young age. They do not want family or relatives in their hometown to worry about the current conditions. Therefore, the self-concept displayed on social media should give the impression of happiness, causing them to upload only content attached to joy.

b. Successful workers

Another self-concept displayed on social media is that of a successful worker. This can be seen from the uploaded content, such as photos using the latest models of clothes, jewelry, or electronic devices. Also, the participants often upload content of various gifts given by employers, accompanied by text descriptions of gratitude. Furthermore, they upload content related to devotion to their families in the village. This was shown by participants 1's upload after buying a cellphone for her mother, while participant 2 said that she had several times uploaded photos of home renovations financed by her wage as domestic workers.

In addition, participant 3 has repeatedly uploaded photos of gift packages for her family in the hometown. These posts show that they want to appear as successful workers that can improve their families' economic conditions. Several uploads show gratitude for still being able to work during the Covid-19 pandemic. Such posts can be categorized as a depiction of a successful participant's self-concept. This concept emerged from their conditions of still being trusted to complete and handle various household tasks, while many other domestic workers have been laid off and experience difficulties finding jobs.

c. Individuals who have an equal social position with other members of society

Another self-concept displayed by the participants is equality with other members of society. This is shown through uploads of photos and statuses showing that they use and perform various activities like others. Multiple posts show them consuming and using the same products as their employers. This can be interpreted to mean that they want to show their positions are equal with other people, in this case, their employers, because 
they use and consume the same products.

The participants also uploaded various conditions. For instance, participant 3 explained that she had uploaded a photo of being sick and being given an IV: "Yes, I just want to upload a photo so people know I get sick too and should be given medicine like other people." The explanation by participant 3 shows that despite being a domestic worker, she is a human who should be treated equally, especially in terms of health. In Indonesia, many employers refuse to procure health insurance for domestic workers (Suryani, 2021) and only offer money to buy medicine once they fall sick. However, health insurance is very important for domestic workers because of long working hours, which prevents them from resting adequately. Moreover, health insurance has become very significant due to the current Covid-19 pandemic, as the workers have to care for their employer's family, who occasionally have activities outside the home (Lui et al., 2021).

This self-concept as an individual equal to others was also influenced by the stereotypes attached to women domestic workers. Therefore, displaying the concept of equality on their social media accounts is significant. The participants wishes to show that they are independent, hard-working individuals who support the ir families even though they are domestic workers.

Also, the results showed that the participants have a significant other on social media that is different from the one offline. The friends and fellow users, who often interact, give a "Like" or "Love" sign, and positive comments are categorized as virtual significant others. This is because the participants considers the acceptance given by friends through various symbols important, and through this interaction, they raise a certain selfconcept on their social media.

Another party that plays a role in the formation of self-concept is the virtual generalized other, as the moral and normative expectations of other social media users regarding various content worth uploading are considered important. For the participants, the virtual generalized other, based on social norms and trending topics, is assumed as a guide in uploading various content.

Generally, the success of the self-concept displayed by the participants depends on the ability to position themselves as subject (I) and object (Me). On social media, participants show that they position themselves as active 
parties (I) by uploading content but also place themselves as objects (me) by allowing other social media users to provide comments and other symbols.

\section{The Meaning of Social Media for the Participants}

In the context of participants who work as domestic workers who work in the employer's private sphere, the social environment of the participants is limited to their employers and employer's families. Then, the participants turned to social media to communicate and interact with family and friends, resulting in high dependence. Furthermore, this channel can maintain and build relationships with other parties and allow interactions as independent individuals.

The results of the study showed that social media is interpreted as a friend or the closest party to convey various feelings. It also provides entertainment and information based on the intensity of the participant's interaction. Therefore, they cannot escape from social media in their daily lives, and it has even become the main channel of interaction. Meanwhile, the participants explained that they were increasingly dependent on social media during the Covid-19 pandemic, as stated by participant 3: "Social media means a lot to me. It is essentially important. Without social media, people would be lonely, missing information, bored, and lack entertainment."

Based on the explanation of the participants above, social media can be considered the only means of entertainment during their busy lives as domestic workers. It is also a means of connecting with the world while having no activities outside the employer's house.

Also, the study results indicated that the participants showed their presence through social media because it is a safe space, where they can present self-concepts and convey narratives that so far cannot appear in offline interactions. Furthermore, it allows them to interact with other users without fear of being humiliated, regardless of their profession as domestic workers. Therefore, social media can be said to have a very important meaning, especially during this Covid-19 pandemic when most of the communication is done by online communication.

According to the results of the research, there are some key points which will be discussed. The results of the study showed that the social media accounts owned by the participants could be identify as the front stage and the back stage. The relationship between the participants with their employer then affects their self-presentation. Participants who have conventional relationships 
with their employer, presented themselves differently on the front stage and the back stage. But on the contrary, participant who has close relationship with their employer presented themselves identically on the front stage and the back stage. This situation experienced by participant 1 .

The employer of participant 1 is still in her 30 s, and there is narrow age gap between participant 1 and her employer. Both of them are accustomed to the use of social media in daily lives. In addition, participant 1 and her employer do have a close relationship. This kind of connections were not found in the relationship between participants 2 and 3 with their respective employers. Their employers have a sizeable age difference of around 20-30 years, so the power relation between them is still very obvious and strong. The results of the research also showed that Facebook and Instagram served as the front stage for the participants. In these social media, they tried to present an ideal version of themselves according to the audience's expectations, in this context were their family, friends, and employers. Therefore, the dominant self-aspect displayed on the front stage is the Me aspect.

Meanwhile, Tik Tok served as the participant's backstage, so the dominant self-aspect that is displayed on the backstage is the I aspect. This is because in Tik Tok they do not network with family members or other friends that they acquainted in the offline realm. So that they can then identify themselves detached from their profession. Social media which serves as the back stage has a very important role because as domestic workers, participants still feel that their position is not equal to other social media users.

There are similarities between the results of previous studies in the west with studies in Indonesia, regarding the use of social media by women who are in a marginal position, including domestic workers. Social media has a very important meaning because it is able to provide safe space for women to construct themselves and their identities, and weaken the construction of society regarding women. This is because of the massive development of technology which then erases various physical boundaries that exist in society. When they have access to technology and use the technology, the boundaries of space and time then disappear.

These results were found in various studies conducted by Kavada (2016), Cauberghe et al.,( 2021)the coronavirus disease 2019 (COVID-19, Sun et al., (n.d.), Boris \& Fish, (2014), dan Wang et al., (2019)most of these studies focus on those behaviors with relatively deep user engagement such as information disclosure, while the underlying mechanisms that explain users' shallow 
engagement behaviors (e.g. Like behavior which showed how technology then gives power to women and other marginalized groups. Through technology they are able to construct new identities, build narratives, and empowered themselves. With the use of technology by the society, power is not only possessed by certain groups, but can be spread evenly in society.

\section{CONCLUSION}

For women who work as domestic workers, social media has a very important meaning for their lives, because through social media they can present themselves according to social expectations on the front stage and be themselves on the back stage. However, for women domestic workers who have close relationships with their employers, and work with employers who have a liberal mindset, they are free to present themselves identically on the front stage and the back stage.

This research focuses on the presentations and interactions which were conducted by the participants in their social media during the Covid-19 pandemic to analyze the meaning of social media for them. A wider focus on interactions that participants conducted in offline interactions, especially with their family and friends in their hometowns before the Covid-19 pandemic can add depth to the research.

\section{ACKNOWLEDGEMENT}

This research is supported by PUTI Doktor 2020 funded by DRPM Universitas Indonesia No. NKB-724/UN2.RST/HKP.05.00/2020.

\section{REFERENCES}

Anggraeni, M. L., \& Diyana, K. (2020). Kumpulan cerita pelik para PRT yang dirumahkan sang majikan karena corona.

Astagini, N. (2016). Presentasi diri pekerja rumah tangga pada situs jejaring sosial Facebook. Aristo, 4(2), 57. https://doi.org/10.24269/ars.v4i2.189

Azeez E P, A., Negi, D. P., Rani, A., \& A P, S. K. (2021). The impact of Covid-19 on migrant women workers in India. Eurasian Geography and Economics, 62(1), 93-112. https://doi.org/10.1080/15387216.2020.1843513 
Boris, E., \& Fish, J. N. (2014). Domestic workers go global. New Labor Forum, 23(3), 76-81. https://doi.org/10.1177/1095796014544508

Bullingham,L., \& Vasconcelos,A.C.(2013). "The presentation of self in theonline world": Goffman and the study of online identities. Journal of Information Science, 39(1), 101-112. https://doi.org/10.1177/0165551512470051

Burnham, L., \& Theodore, N. (2012). The invisible and unregulated world of domestic work. http://www.idwfed.org/en/resources/home-economicsthe-invisible-and-unregulated-world-of-domestic-work/@@isplay-file/ attachment_1

Cauberghe, V., Van Wesenbeeck, I., De Jans, S., Hudders, L., \& Ponnet, K. (2021). How adolescents use social media to cope with feelings of loneliness and anxiety during Covid-19 lockdown. Cyberpsychology, Behavior, and Social Networking, 24(4), 250-257. https://doi.org/10.1089/ cyber.2020.0478

Creswell, J. W., \& Creswell, J. D. (2018). Research design: Qualitative, quantitative, and mixed methods approaches (5th ed.). Sage Publication, Inc.

Davis, J. L. (2014). Triangulating the self: Identity processes in a connected era. Symbolic Interaction, 37(4), 500-523. https://doi.org/10.1002/SYMB.123

de Villiers, B., \& Taylor, M. (2019). Promoting a positive work experience for South African domestic workers. SA Journal of Human Resource Management, 17, 1-13. https://doi.org/10.4102/sajhrm.v17i0.1206

Djafarova, E., \& Trofimenko, O. (2019). 'Instafamous'-credibility and self-presentation of micro-celebrities on social media. Information Communication and Society, 22(10), 1432-1446. https://doi.org/10.1080/ 1369118X.2018.1438491

Galvaan, R., Peters, L., Smith, T., Brittain, M., Menegaldo, A., Rautenbach, N., \& Wilson-Poe, A. (2015). Employers' experiences of having a livein domestic worker: Insights into the relationship between privilege and occupational justice. South African Journal of Occupational Therapy, 45(1), 41-46. https://doi.org/10.17159/2310-3833/2015/v45no1a7

Hidayati, M. N. (2011). Upaya perlindungan pekerja rumah tangga sebagai kelompok masyarakat yang termarjinalkan di Indonesia. 39(1), 11-18.

Hogan, B. (2010). The Presentation of self in the age of social media: Distinguishing performances and exhibitions online. Bulletin of Science, Technology $\mathbb{E}$ Society, 30(6), 377-386. https://doi.org/10.1177/0270467610385893 
Housley, W. (2021). Society in the Digital Age: An interactionist perspective. Sage Publication.

International Labour Organization. (2006). Peraturan tentang pekerja rumah tangga di Indonesia.

International Labour Organization. (2013). Working time of live-in domestic workers. 1-8.

Kavada, A. (2016). Social movements and political agency in the digital age: A communication approach. Media and Communication, 4(4), 8-12. https:// doi.org/10.17645/mac.v4i4.691

Kerrigan, F., \& Hart, A. (2016). Theorising digital personhood: a dramaturgical approach. Journal of Marketing Management, 32(17-18), 1701-1721. https://doi.org/10.1080/0267257X.2016.1260630

Krisdiyanto, T. (2021). Analisis sentimen opini masyarakat Indonesia terhadap kebijakan PPKM pada media sosial Twitter menggunakan naïve bayes clasifiers. Jurnal CoreIT: Jurnal Hasil Penelitian Ilmu Komputer dan Teknologi Informasi, 7(1). https://doi.org/http://dx.doi.org/10.24014/coreit. v7i1.12945

Lui, I. D., Vandan, N., Davies, S. E., Harman, S., Morgan, R., Smith, J., Wenham, C., \& Grépin, K. A. (2021). "We also deserve help during the pandemic": The effect of the Covid-19 pandemic on foreign domestic workers in Hong Kong. Journal of Migration and Health, 3(February), 100037. https://doi.org/10.1016/j.jmh.2021.100037

Markham, A. N., \& Lindgren, S. (2014). From object to flow: Network sensibility, symbolic interactionism, and social media. Symbolic Interaction and New Social Media, 34(1), 43-61. https://doi.org/http://dx.doi.org/10.1108/ S0163-239620140000043012

Pandey, K., Parreñas, R. S., \& Sabio, G. S. (2021). Essential and expendable: Migrant domestic workers and the Covid-19 pandemic. American Behavioral Scientist, 1-15. https://doi.org/10.1177/00027642211000396

Platt, M., Yeoh, B. S. A., Acedera, K. A., Yen, K. C., Baey, G., \& Lam, T. (2016). Renegotiating migration experiences: Indonesian domestic workers in Singapore and use of information communication technologies. New Media and Society, 18(10), 2207-2223. https://doi. org/10.1177/1461444816655614 
Putri, K. Y. S., \& Zakiah, L. (2021). Transformation of health communication literacy in the pandemic era. Informasi, 51(1), 93-110.

Redmond, M. V. (2015). Symbolic interactionism symbolic interactionism communication context. English Technical Reports and White Papers, 4. http://lib.dr.iastate.edu/engl_reports/4

Retnaningdyah, P. (2013). 'Kami Juga Punya Suara': Dunia blogging buruh migran Indonesia di Hong Kong sebagai politik budaya. Jurnal Komunikasi Indonesia, II(April), 23-30.

Sari, D. K., \& Siahainenia, R. R. (2015). Gerakan sosial baru di ruang publik virtual pada kasus Satinah. Jurnal ILMU KOMUNIKASI, 12(1), 105-118. https://doi.org/10.24002/jik.v12i1.446

Sigiro, A. N., Gina, A., Komalasari, D., \& Pratiwi, A. M. (2020). Portrait of the impact of the implementation of large-scale social distancing during Covid-19 pandemic towards women and marginalized groups through the perspective of intersectional feminism. Jurnal Perempuan, 25(4), 295. https://doi.org/10.34309/jp.v25i4.514

Sun, R., Rieble, C., Liu, Y., \& Sauter, D. (n.d.). Connected despite lockdown: The role of social interactions and social media use in wellbeing.

Suryani, L. (2021). Kerja 15 Jam Perhari; Kelelahan Kerja, PRT Rentan Terkena Covid. Konde.Co. https://www.konde.co/2021/07/curhat-prt-kelelahankerja-bisa-jadi-penyebab-prt-terkena-covid-19.html/

Tomei, M. (2011). Decent work for domestic workers: Reflections on recent approaches to tackle informality. Canadian Journal of Women and the Law, 23(1), 185-211. https://doi.org/10.3138/cjwl.23.1.185

Ujianto, A. (2019). Pengorganisasian komunitas serikat pekerja rumah tangga Sapulidi dalam memperjuangkan situasi kerja layak. Kajian Ruang Sosial Budaya, 3(1), 1-17. https://doi.org/10.21776/ub.sosiologi. jkrsb.2019.003.1.08

Vardanega, A. (2015). Symbolic interactionism. The International Encyclopedia of Political Communication, 1-8. https://doi.org/10.1002/9781118541555. wbiepc090

Wang, N., Sun, Y., Shen, X. L., Liu, D., \& Zhang, X. (2019). Just being there matters: Investigating the role of sense of presence in Like behaviors from the perspective of symbolic interactionism. Internet Research, 29(1), 6081. https://doi.org/10.1108/IntR-08-2017-0299 
Informasi, Vol. 51. No. 2. (2021), 227-248

Wängqvist, M., \& Frisén, A. (2016). Who am i online? Understanding the meaning of online contexts for identity development. Adolescent Research Review, 1(2), 139-151. https://doi.org/10.1007/s40894-016-0025-0 